\title{
DESAIN APLIKASI FINANCIAL TECHNOLOGY (FINTECH) PADA PEREMPUAN KORBAN PHK TERDAMPAK COVID - 19 DENGAN SISTEM REDISTRIBUSI PENGHASILAN BERBASIS LAYANAN FILANTROPI
}

\author{
Carolina Ety Widjayanti', Dhany Faizal Racma², Antonius Ary Setyawan ${ }^{3}$ \\ ${ }^{1}$ Program Studi Komputerisasi Akuntansi, STIKOM Yos Sudarso* \\ Email: carolinaety@stikomyos.ac.id \\ ${ }^{2}$ Program Studi Sistem Informasi, STIKOM Yos Sudarso \\ Email: dhany.faizal@stikomyos.ac.id \\ ${ }^{3}$ Program Studi Sistem Informasi, STIKOM Yos Sudarso \\ Email: arysetpr@stikomyos.ac.id
}

Masuk : 01-10-2021, revisi: 23-10-2021, diterima untuk diterbitkan : 29-01-2021

\begin{abstract}
ABSTRAK
Dampak krisis ekonomi global akibat Pandemik Virus Corona atau Covid-19 sangat dirasakan oleh seluruh penduduk dunia, termasuk masyarakat Indonesia. Banyak Industri Bangkrut yang mengakibatkan kenaikan PHK meningkat khususnya perempuan, mengingat peran wanita sangat besar dan menjadi penopang ekonomi keluarga; maka peran wanita ini perlu diperkuat lagi, sehingga kelangsungan hidup keluarga mereka akan terjamin. Disamping itu, dinamika lapangan membutuhkan solusi kreatif untuk meningkatkan inklusi keuangan. Salah satunya lewat pemanfaatan sektor layanan filantropi. Dalam kondisi ekonomi yang sulit pada masa pandemi virus corona (Covid-19) di Indonesia tidak membuat filantropi masyarakat menurun, sebaliknya justru cenderung terus meningkat. Model bisnis filantropi yang akan dibangun dengan mempertemukan antara para donatur dan pekerja wanita yang terdampak covid-19. Mereka bisa langsung berinteraksi tanpa perlu kehadiran intermediary. Metode penelitian yang digunakan adalah menggunakan metode Waterfall yang meliputi tahap analisis (analysis), tahap perancangan (design), tahap implementasi (implementation), tahap pengujian (testing) antara lain blackbox, whitebox dan Usability dengan pengujian SUS (System Usability Scale). Hasil pengujian System Usability Scale (SUS) rata-rata skor SUS sebesar 86,5 yang berarti sistem layak digunakan. Diharapkan dengan adanya platform e-sharing ini, dapat memfasilitasi masyarakat yang berpendapatan tetap atau yang tidak memiliki resiko kehilangan pekerjaan di tengah pandemi ini untuk mendistribusikan sebagian kecil kekayaannya dalam format egaliter ke mereka yang dirugikan restriksi Covid-19.
\end{abstract}

Kata Kunci: Fintech; filantropi; platform; PHK

\begin{abstract}
The impact of the global economic crisis due to the Corona Virus Pandemic or Covid-19 is felt by the entire world population, including the people of Indonesia. Many Bankrupt Industries have resulted in an increase in layoffs, especially for women, considering the very large role of women and being the supporter of the family economy; then the role of this woman needs to be strengthened again, so that the survival of their family will be guaranteed. In addition, the dynamics of the field require creative solutions to increase financial inclusion. One of them is through the use of the philanthropic service sector. In the difficult economic conditions during the corona virus (Covid-19) pandemic in Indonesia, this did not reduce public philanthropy, on the contrary, it tends to continue to increase. A philanthropic business model that will be built by bringing together donors and female workers affected by Covid-19. They can interact directly without the need for an intermediary. The research method used is the Waterfall method which includes the analysis phase, the design phase, the implementation phase, the testing phase, including blackbox, whitebox and usability testing with SUS (System Usability Scale). The results of the System Usability Scale (SUS) test have an average SUS score of 86.5, which means the system is feasible to use. It is hoped that with this e-sharing platform, it can facilitate people who have a fixed income or who do not have the risk of losing their jobs in the midst of this pandemic to distribute a small portion of their wealth in an egalitarian format to those who are disadvantaged by the Covid-19 restrictions.
\end{abstract}

Keywords: Fintech; filantropi; platform; PHK 


\section{PENDAHULUAN}

\section{Latar Belakang}

Dampak krisis ekonomi global akibat pandemik Covid-19 sangat dirasakan oleh seluruh penduduk dunia, termasuk masyarakat Indonesia. Banyak pengusaha yang menyatakan sulit bertahan saat situasi krisis saat ini dan beberapa diantara mereka memberikan penawaran kepada karyawannya untuk mengambil cuti tak berbayar (unpaid leave) alias dirumahkan. Ini dilakukan agar perusahaan tetap bertahan saat mereka mengalami pukulan yang sangat berat akibat pandemi Covid-19 (Dewi et al., 2020).

Beberapa pengusaha Pemerintah menyebutkan bahwa angka Pemutusan Hubungan Kerja (PHK) sebagai dampak dari virus corona atau Covid-19 telah mencapai 3,05 juta orang. Sedangkan di Kabupaten Banyumas, data yang diambil dari Dinas Tenaga Kerja per Juni 2020, menyebutkan bahwa data karyawan yang dirumahkan mencapai angka 5.625 orang yang terdiri dari perempuan sebanyak 1.562 dan laki-laki 4.063 dan total karyawan yang diPHK karena Covid-19 sebesar 223 orang yang terdiri dari 156 pekerja perempuan dan 67 pekerja laki-laki. Jumlah pekerja korban PHK perempuan lebih banyak dibanding laki-laki.

Peran perempuan saat ini sudah mulai berorientasi global, aktif dan menjadi perempuan yang mandiri. Bahkan, perempuan menjadi tulang punggung keluarga, pengambil kebijakan di berbagai instansi, pendapatannya bahkan melebihi suami sebagai kepala rumah tangga (Sari \& Fikri Zufar, 2021). Mengingat korban PHK di Kabupaten Banyumas didominasi oleh pekerja perempuan, sedangkan dalam hal ini, banyak perempuan yang menjadi penopang ekonomi keluarga tentunya dalam situasi pandemik Covid-19 ini hidup keluarga mereka menjadi terganggu bahkan terancam dari kemiskinan.

Salah satu usaha yang dapat dilakukan untuk memperkuat peran wanita tersebut dengan memanfaatkan teknologi digital yang dalam beberapa tahun terakhir telah mengalami kemajuan yang sangat pesat. Saat ini pemanfaatan teknologi digital ini telah mempengaruhi juga perubahan pola pikir dan kebiasaan masyarakat, termasuk wanita dalam menjalani kehidupan mereka sehari-hari. Dengan memanfaatkan teknologi digital (Burhanuddin \& Abdi, 2019), mereka dapat melakukan pekerjaan dengan mudah, mendapatkan sesuatu dengan segera, atau berkomunikasi dengan orang lain tanpa harus tatap muka, sehingga dengan modal keterampilan memanfaatkan teknologi digital ini, warga masyarakat khususnya wanita dapat menjalankan usahanya dengan lebih cepat dan lebih mudah.

Dengan melihat fenomena pada masa pandemik Covid-19, dimana kepedulian masyarakat meningkat untuk saling berbagi sehingga roda ekonomi masyarakat tetap bergerak dan berputar bahkan di masa sulit ini, membuat filantropi masyarakat justru cenderung terus meningkat. (Jusuf, 2007)

Maka melihat uraian latar belakang diatas, hubungan antara Dampak Covid-19, Korban PHK terutama perempuan dan semangat filantropi yang tinggi serta pemanfaatan teknologi digital(Fintech)(Nizar, 2017). Penulis berupaya membuat desain platform yang dapat memfasilitasi permasalahan tersebut, sehingga ada ketercukupan ekonomi bagi perempuan PHK untuk menopang keluarganya.

\section{Rumusan Masalah}

Bagaimana membangun platform yang dapat memfasilitasi masyarakat yang memiliki pendapatan rutin dan jauh dari resiko kehilangan pekerjaan dengan pekerja perempuan yang terkena PHK yang terdampak Covid-19 untuk berpartisipasi baik dalam bentuk mendistribusikan dana maupun ide atau etalase bisnis yang dijalankan ke akun Financial Digital Tecnology (Fintech)? 


\section{Tujuan}

a. Mempertemukan kelompok filantropi yaitu para donatur yang memiliki kedermawanan atau suka membantu sesama dengan perempuan yang terkena PHK yang terdampak Covid-19.

b. Membangun platform (Redistribusi Pendapatan) yang dapat memfasilitasi masyarakat yang memiliki pendapatan rutin dan jauh dari resiko kehilangan pekerjaan, untuk berpartisipasi baik dalam bentuk mendistribusikan dana maupun etalase bisnis yang dijalankan ke akun Fintech pada pekerja perempuan yang terkena PHK yang terdampak Covid-19.

\section{METODE PENELITIAN}

Metodologi yang digunakan dalam penelitian ini adalah model pengembangan Waterfall. Adapun tahapan dalam model pengembangan waterfall adalah tahap analisis (analysis), tahap perancangan (design), tahap implementasi (implementation), tahap pengujian (testing).

\section{Tahap Analisis}

Pada tahap analisis ini, dilakukan analisis kebutuhan sistem dalam mendukung kinerja aplikasi, apakah aplikasi yang dibuat sudah sesuai dengan kebutuhan pengguna atau belum. Untuk mempermudah melakukan analisis kebutuhan sistem, diperlukan pengelompokan analisa kebutuhan sistem, yaitu :

\section{Analisa Kebutuhan Fungsional}

Kebutuhan fungional adalah kebutuhan yang berisi proses-proses apa saja atau layanan apa saja yang nantinya harus disediakan oleh sistem, mencakup bagaimana sistem harus bereaksi pada input tertentu dan bagaimana perilaku sistem pada situasi tertentu. Berikut beberapa kebutuhan fungsional dari sistem:

a. Pemberi Donasi,

Donasi yang diberikan dapat berupa dana dan etalase bisnis/ide bisnis.

Sedangkan pemberi donasi yang dimaksud adalah masyarakat yang mempunyai pendapatan rutin dan jauh dari resiko kehilangan pekerjaan.

b. Penerima Donasi,

Penerima donasi adalah perempuan korban PHK terdampak covid-19.

c. Admin

\section{Analisa Kebutuhan Non Fungsional}

Kebutuhan Non Fungsional merupakan kebutuhan lain yang tidak termasuk fungsi atau proses adalah sebagai berikut :

a. Kebutuhan Perangkat Lunak (Software)

Kebutuhan spesifikasi software atau perangkat lunak yang digunakan dalam aplikasi ini adalah:

- Sistem Operasi : Server : CentOS 764 bit, Personal Computer : Windows 1064 bit

- XAMPP yang terdiri dari : Apache Server, MYSQL, PHP.

- Bahasa Pemrograman : PHP, HTML, JavaScrip, Ajax, Fluter Framework, Codeigniter Framework, Java, JSON

- SDK : Android Studio, Flutter Plugin, Visual Studio Code

- Database : MYSQL

- Web Browser : Google Chrome, Mozila Firefox, Opera, Edge 


\section{b. Kebutuhan Perangkat Keras (Hardware)}

Perangkat keras atau hardware adalah semua peralatan fisik komputer yang memilki kriteria tertentu. Dalam pembuatan aplikasi ini, perangkat keras atau hardware yang digunakan adalah sebagai berikut :

- Server : Processor Intel Xeon Gold, Memory 2 GB, Storage SSD20 GB

- Personal Computer : Processor MD Ryzen 5, Memory 8 GB, Strorage SSD 500 GB

- Keyboard dan Mouse yang kompatibel.

- Printer dan Scan PIXMA G570

\section{Tahap Perancangan (Design)}

Dalam tahapan proses membuat tampilan dasar dari sitem yang akan dibuat oleh peneliti, hal ini bertujuan untuk memberikan dasar dalam perancangan sistem agar sistem yang dibuat sesuai dengan dengan tujuan.

\section{Tahap Pengujian (Testing)}

Pengujian sistem ini dilakukan untuk mengetahui apakah sistem yang dirancang sudah sesuai dengan tujuannya belum, dan dalam pengujian ini juga dapat melihat kinerja sistem sebelum diimplementasikan kepada pihak pengguna. Pengujian yang dilakukan antara lain dengan pengujian whitebox dan blackbox serta uji Usability. Pengujian Whitebox dilakukan dengan perangkat lunak dari segi desain dan kode program apakah mampu menghasilkan fungsi-fungsi, masukan dan keluaran yang sesuai dengan spesifikasi kebutuhan. Dan Pengujian Blackbox dilakukan pengujian terhadap elemen-elemen dalam aplikasi apakah berfungsi dengan baik atau tidak. Sedangkan Pengujian Usabililty dilakukan untuk mengetahui seberapa efektif, efisien dan memuaskan sebuah sistem menurut penggunanya (Marthasari \& Hayatin, 2017). Dalam Pemilihan Responden Usability Testing menurut Krug (Steve Krug, 1985) mengatakan bahwa: "In most cases, I tend to think the ideal number of users for each round of testing is three, or at most four"atau bisa diartikan dalam " kebanyakan kasus, saya cenderung berpikir jumlah pengguna yang ideal untuk setiap putaran pengujian tiga, atau empat paling banyak", sedangkan Menurut Rusidi (Rusidi, 2011), pemilihan responden yang akan memberikan isian terhadap kuesioner sejumlah tiga orang dengan pemisahan yaitu satu orang pengguna aktif (terampil menggunakan internet dan sering mengakses situs website), satu orang pengguna terampil (terampil menggunakan internet) dan satu orang pengguna awam. Oleh karena itu 5 (lima) orang responden sudah cukup untuk menguji usabilitas sebuah produk (Nielsen, 2000).

Pengujian Usability dengan menggunakan SUS (System Usability Scale) berupa kuesioner yang terdiri dari 10 item (H.N et al., 2015) pertanyaan ditampilkan dalam Tabel 1.

\section{Tabel 1. Item Pertanyaan System Usability Scale (SUS)}

\begin{tabular}{cl}
\hline Kode & \\
\hline 1 & Saya akan menggunakan sistem ini lagi \\
2 & Saya menilai sistem ini sangat kompleks (memuat hal yang tidak perlu) \\
3 & Saya menilai sistem ini mudah digunakan \\
4 & Saya membutuhkan bantuan dari orang lain atau teknisi dalam menggunakan sistem ini. \\
5 & Saya merasa fitur-fitur yang disediakan pada sistem ini dirancang dan disiapkan dengan baik. \\
6 & Saya merasa ada banyak hal yang tidak konsisten (tidak serasi pada sistem ini). \\
7 & Saya merasa orang lain akan mudah menggunakan sistem ini dengan cepat. \\
8 & Saya merasa sistem ini membingungkan \\
9 & Saya merasa tdak ada hambatan dalam menggunakan sistem ini. \\
10 & Saya perlu belajar terlebih dahulu sebelum menggunakan sistem ini \\
\hline
\end{tabular}


Kuesioner SUS menggunakan 5 skala Likert, yaitu 1. Sangat Tidak Setuju, 2. Tidak Setuju, 3. Ragu-ragu, 4. Setuju dan 5. Sangat Setuju. Setelah data-data kuesioner yang diberikan kepada responden terkumpul, selanjutnya akan melakukan konversi tanggapan responden dengan menghitung dengan rumus perhitungan skor SUS :

Skor $S U S=((\mathrm{R} 1-1)+(5-\mathrm{R} 2)+(\mathrm{R} 3-1)+(5-\mathrm{R} 4)+(\mathrm{R} 5-1)+(5-\mathrm{R} 6)+(\mathrm{R} 7-1)+(5-\mathrm{R} 8)+(\mathrm{R} 9-1)+(5-\mathrm{R} 10)) * 2.5)$

$\mathrm{R}$ merupakan kode item pertanyaan, dimana skor keseluruhan diperoleh dari rata-rata skor SUS individual.

\section{HASIL DAN PEMBAHASAN}

Tahap Perancangan (Design)

1. Perancangan Diagram Use Case

Use case diagram berfungsi untuk menjelaskan dalam bentuk gambar mengenai siapa saja aktor yang terlibat di sistem, fungsi apa saja yang bisa dilakukan oleh sistem, dan mendeskripsikan interaksi pengguna dengan sistem informasi. Disajikan dalam gambar 1 .

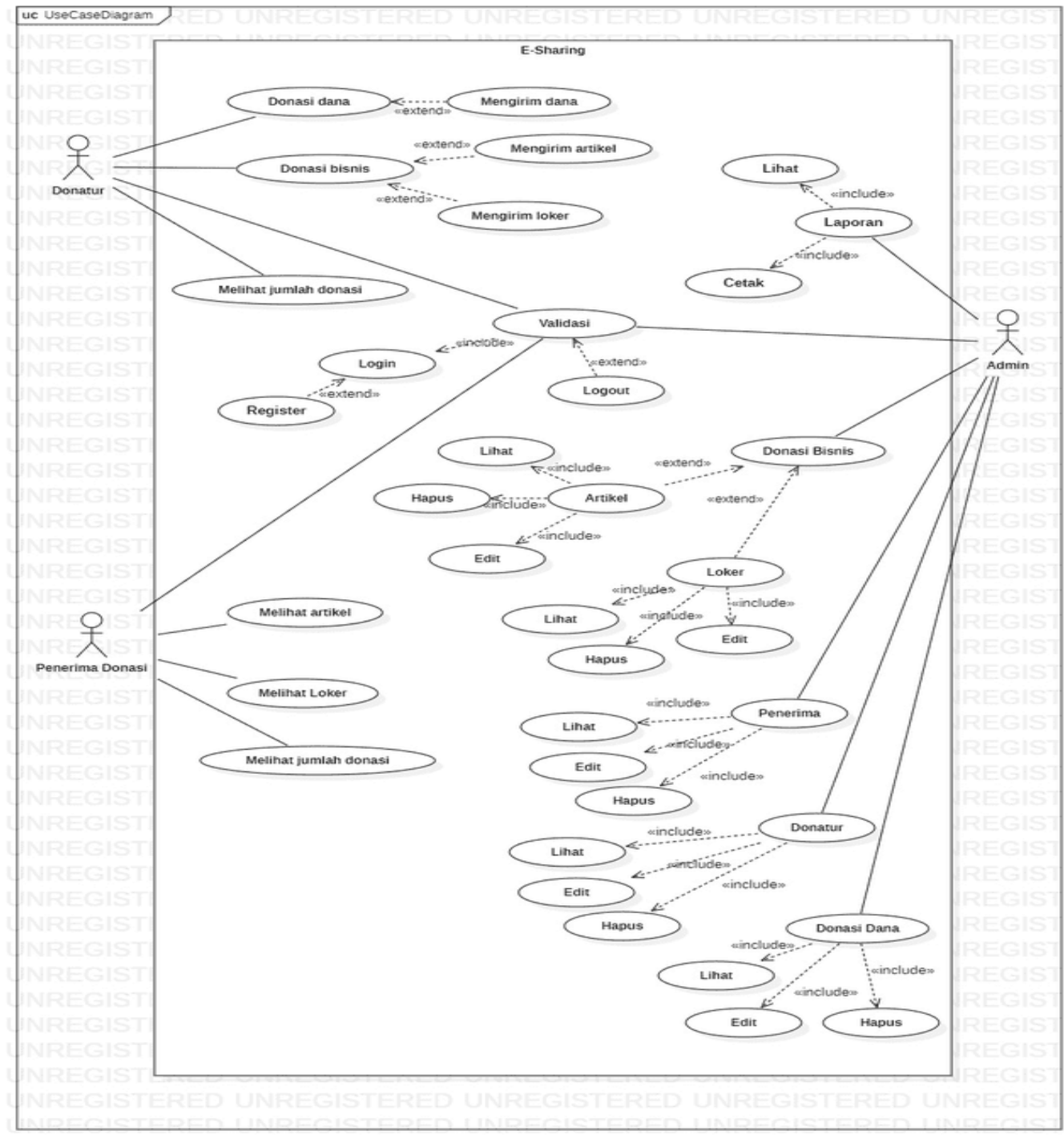

Gambar 1. Usecase secara keseluruhan 


\section{Perancangan Tampilan Dasar Sistem}

a. Pada Gambar 2. Dapat disajikan halaman home mockup menu e-sharing

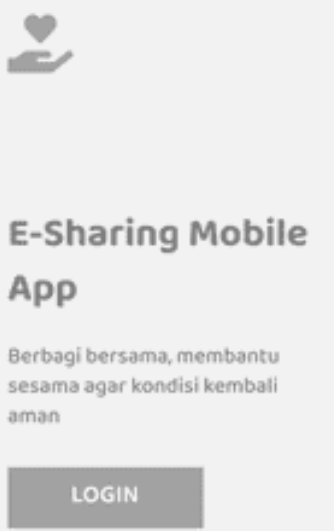

Gambar 2. Mock up tampilan home

b. Pada Gambar 3. Dapat disajikan halaman login mockup menu $e$-sharing

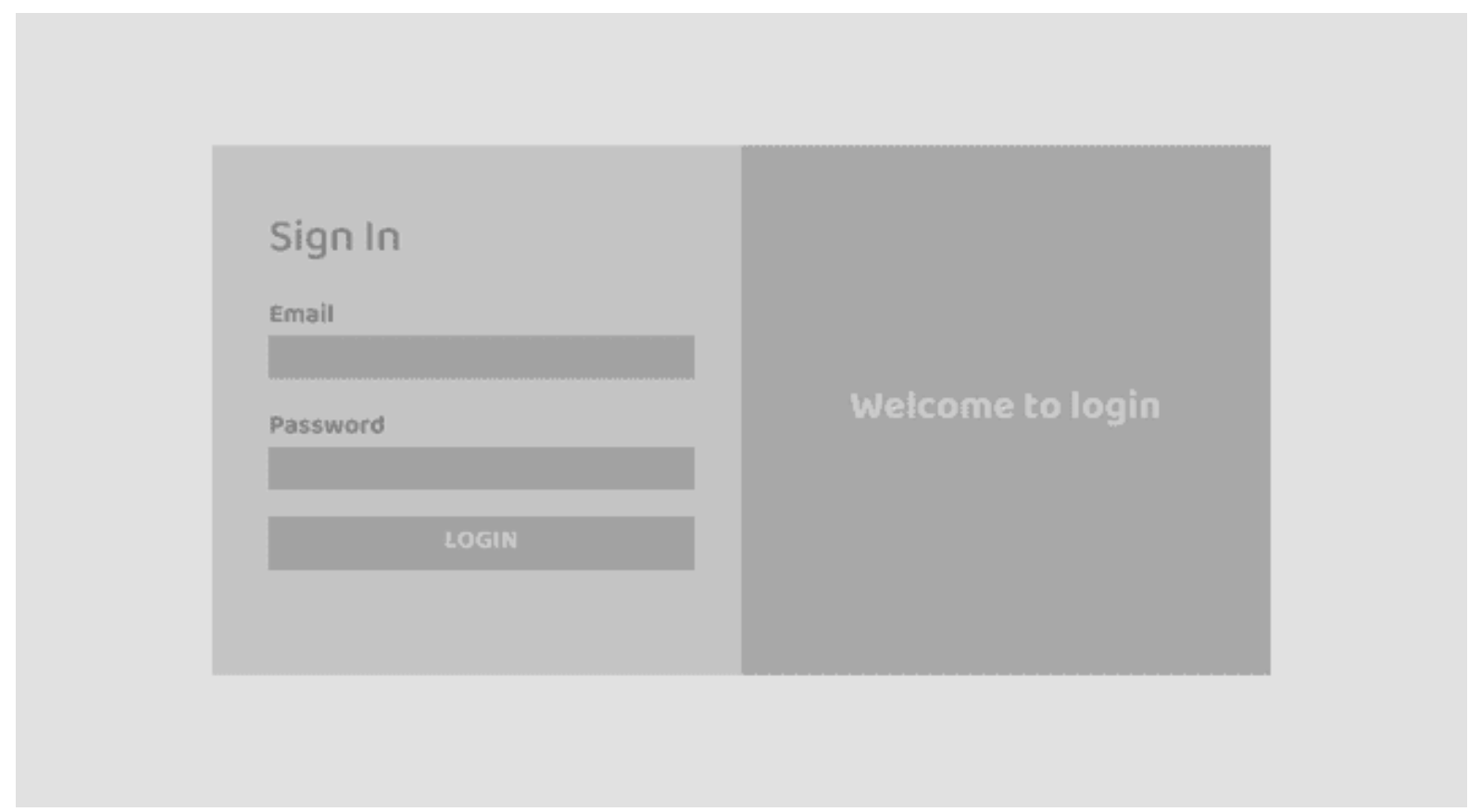

Gambar 3. Mock up tampilan login 
Jurnal Muara Sains, Teknologi, Kedokteran, dan Ilmu Kesehatan

ISSN 2579-6402 (Versi Cetak)

Vol. 5, No. 2, Oktober 2021: hlm 597-612

ISSN-L 2579-6410 (Versi Elektronik)

c. Pada Gambar 4. Dapat disajikan halaman admin menu e-sharing

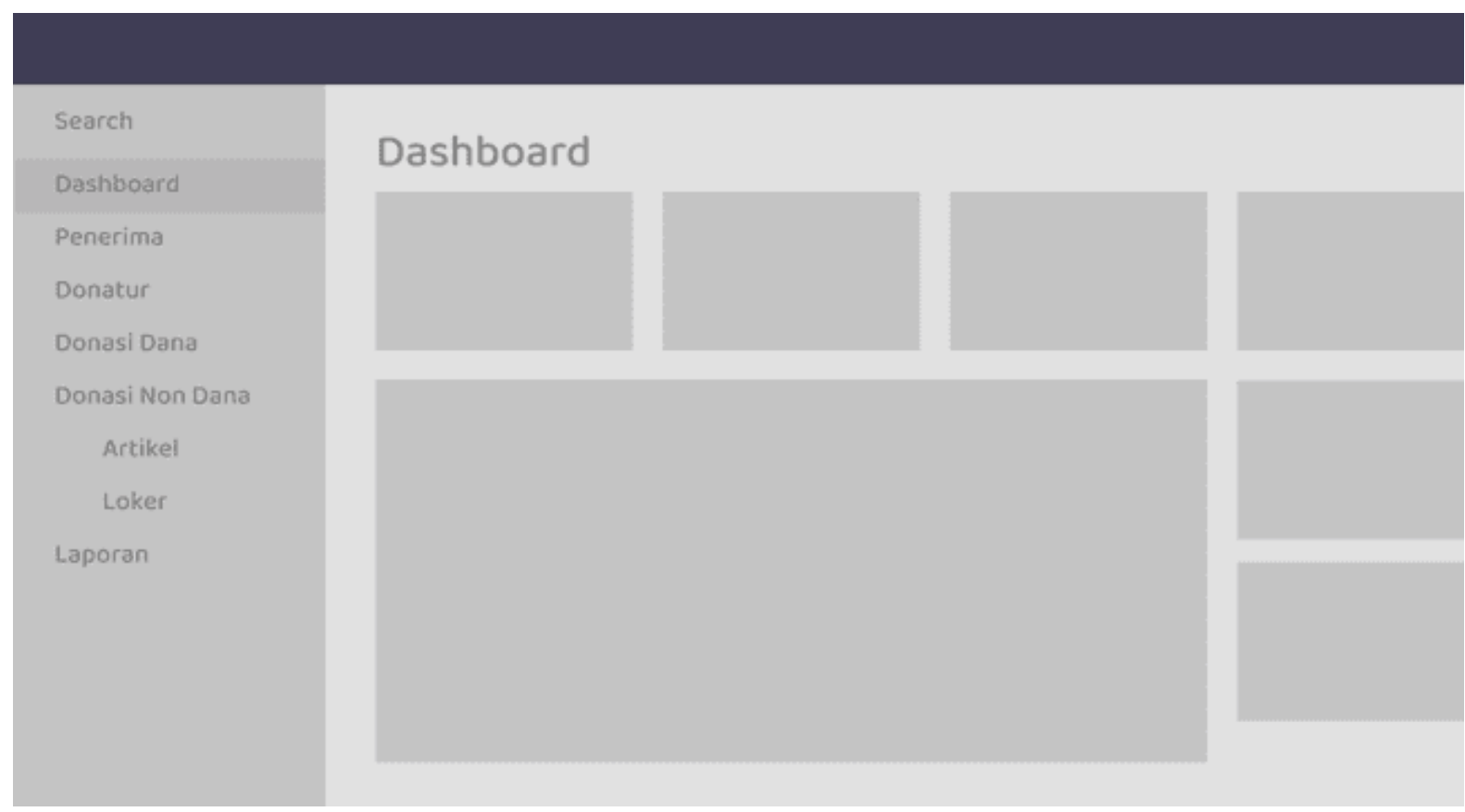

Gambar 4. Mock up tampilan admin

d. Pada Gambar 5. Dapat disajikan halaman pemberi donasi dana menu e-sharing

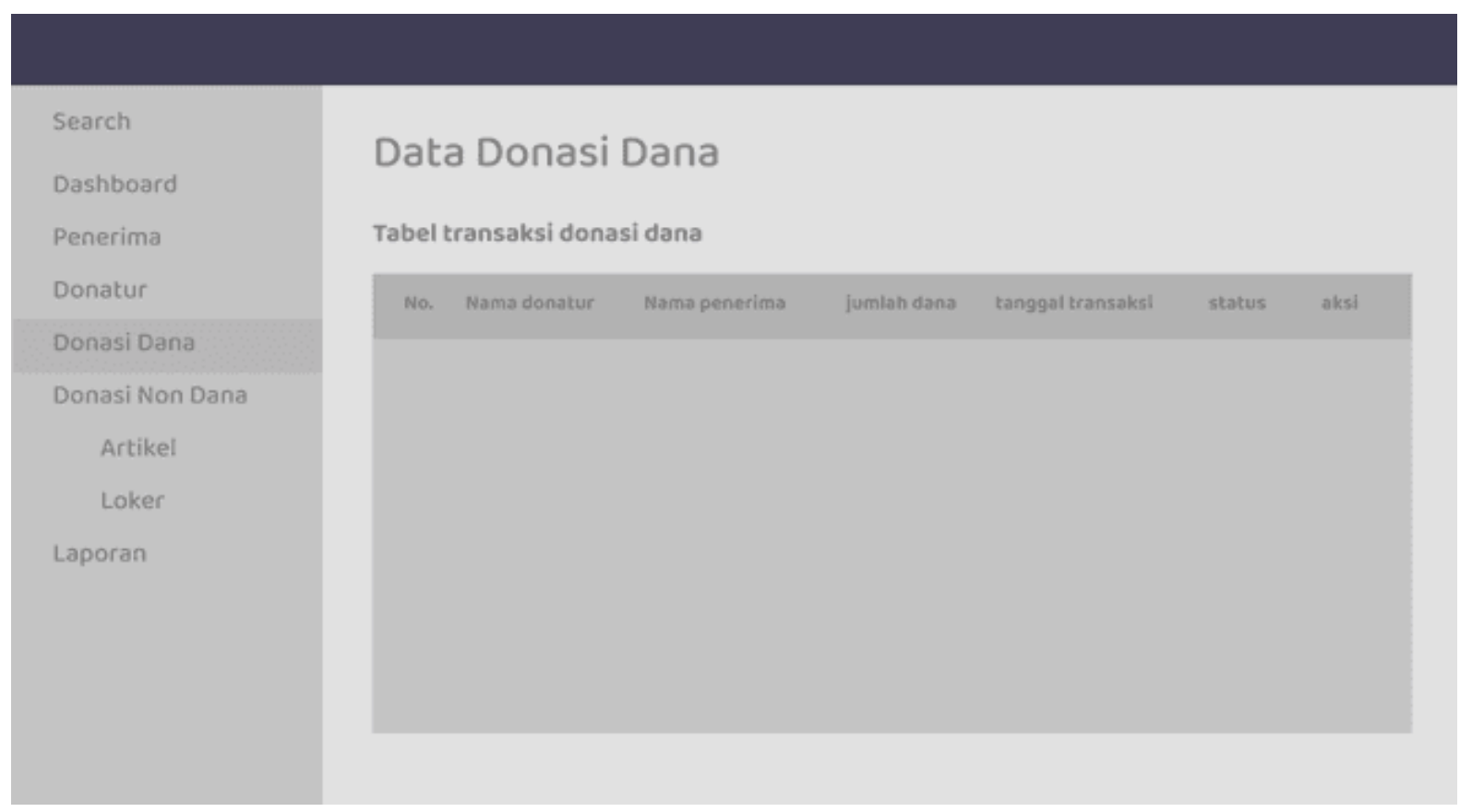

Gambar 5. Mock up tampilan pemberi donasi dana 
e. Pada Gambar 6. Dapat disajikan halaman penerima donasi dana menu $e$-sharing

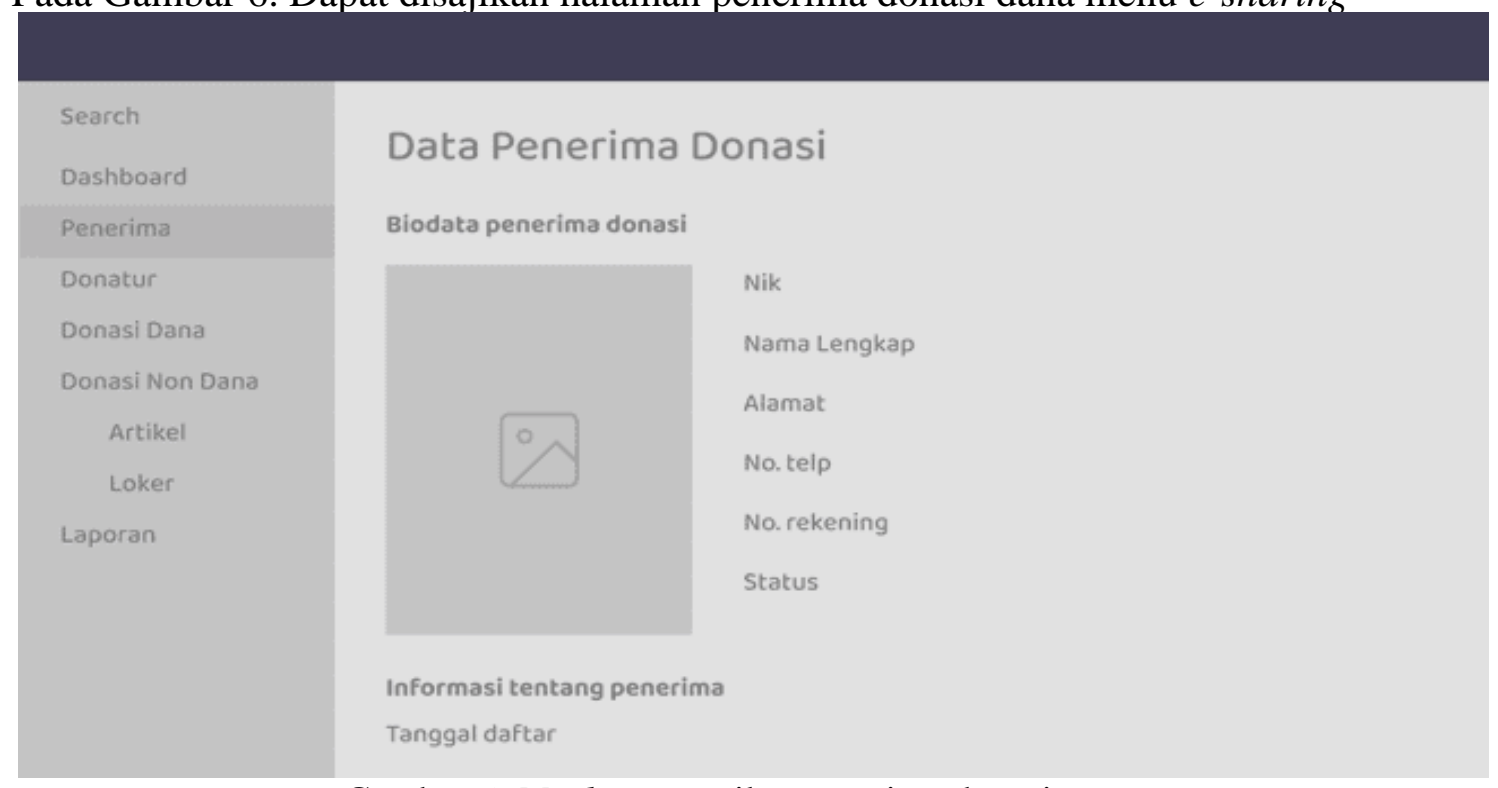

Gambar 6. Mock up tampilan penerima donasi

2. Proses Pengcodingan Sistem.

Setelah proses pembuatan desain tampilan mockup sudah terbentuk, maka proses selanjutnya adalah proses pembuatan coding sistem, dimana proses ini merupakan kegiatan penulisan dan pengumpulan serangkaian perintah untuk membuat sebuah program komputer.

\section{Tahap Implementasi dan Pengujian}

\section{Tahap Pengembangan}

Pada tahap pengembangan ini untuk mengevaluasi dengan menguji apakah desain platform $e$ sharing sudah sesuai dengan kebutuhan pengguna atau belum, bila tidak maka desain akan dikembangkan lagi.

a. Tampilan Sistem

Disajikan pada gambar 9. Tampilan halaman home, terdapat informasi singkat mengenai $e$ sharing. Disamping itu ada menu login, untuk masuk kedalam aplikasi tersebut.

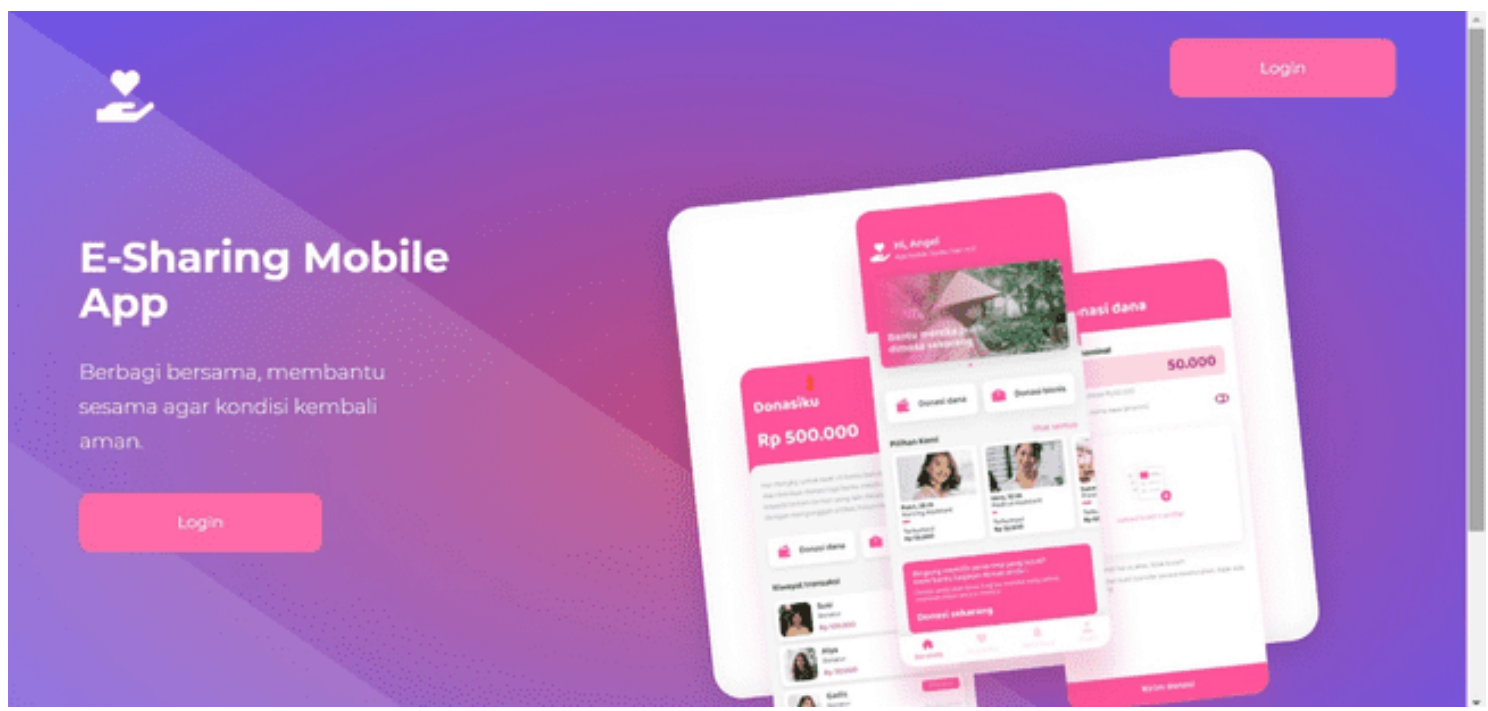

Gambar 9. Tampilan menu home 


\section{b. Tampilan Login}

Pada gambar 10 disajikan mengenai tampilan login, yang berisi selamat datang, lalu cara masuk kedalam aplikasi $e$-sharing.

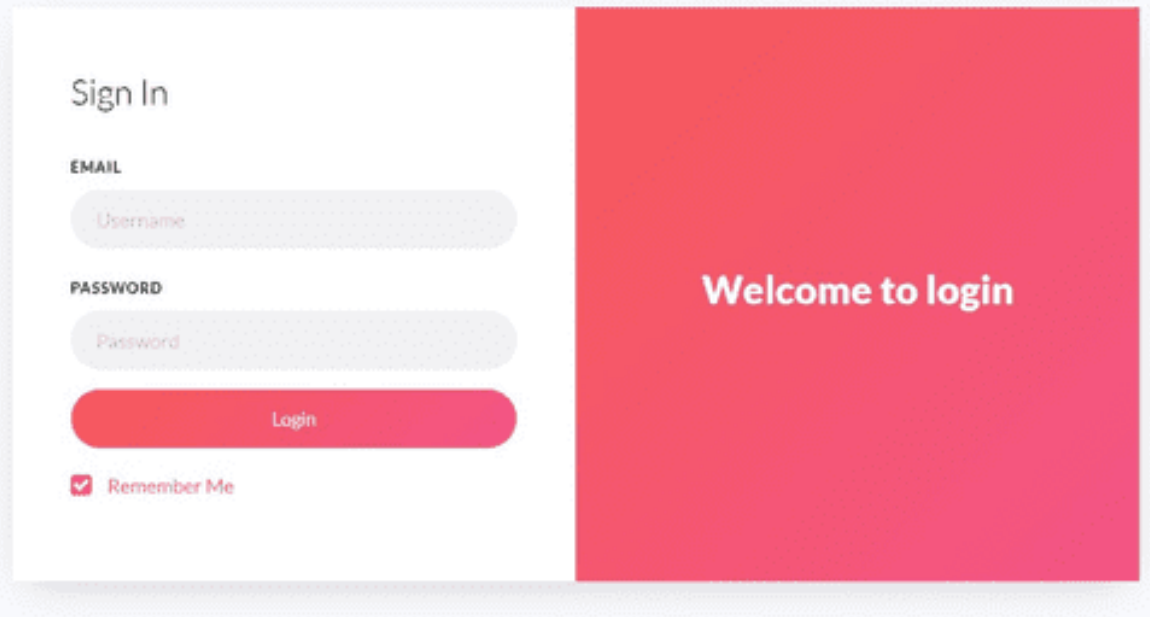

Gambar 10. Tampilan menu login

c. Tampilan admin

Pada gambar 11 disajikan mengenai tampilan menu admin, yang berisi informasi mengenai anggota, donatur dalam bentuk donasi dana maupun donasi non dana, kemudian terdapat validasi dokumen registrasi dan laporan pemberian dan penerimaan donasi.

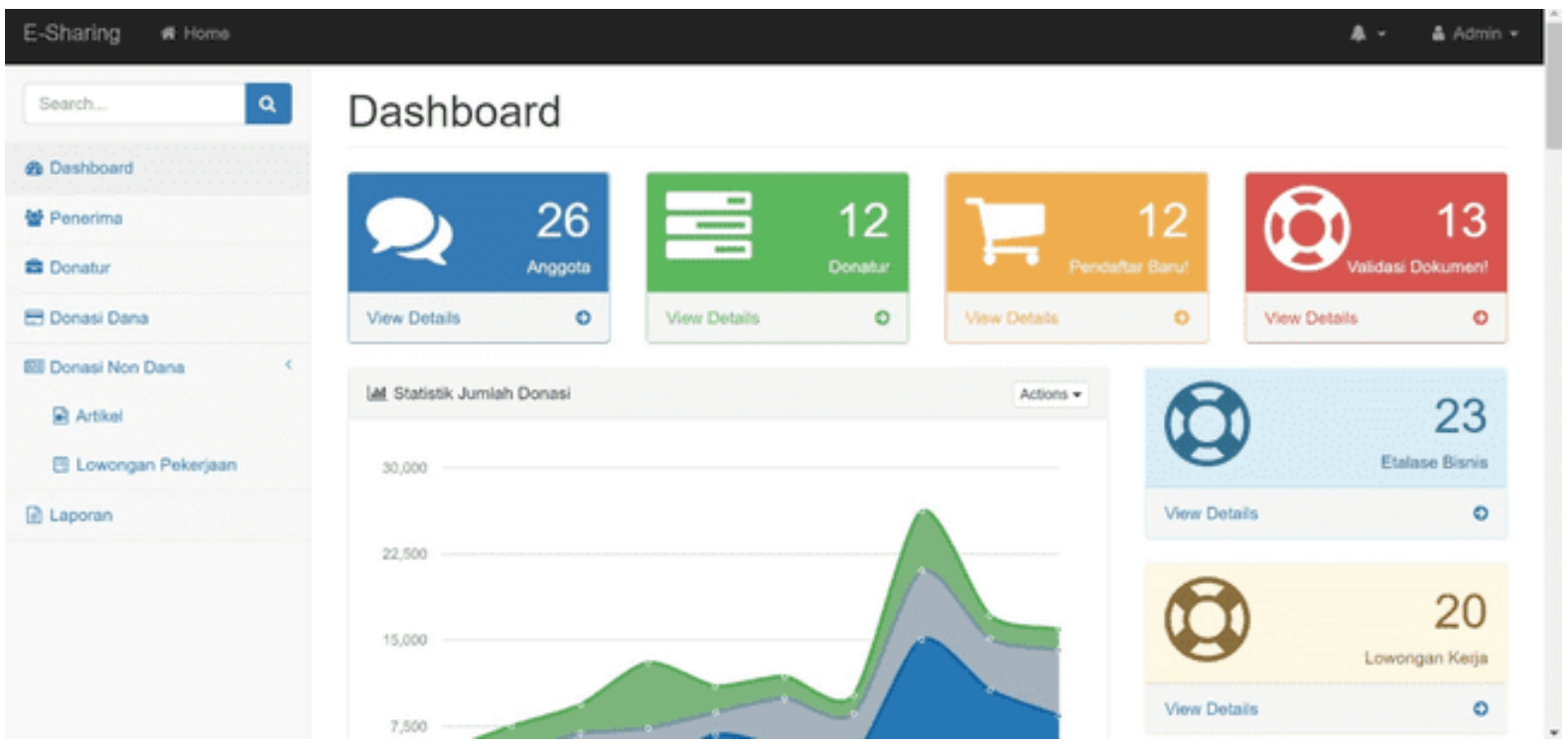

Gambar 11. Tampilan menu admin 


\section{d. Tampilan pemberi donasi}

Pada gambar 12 disajikan mengenai informasi nama donatur, kelengkapan data pemberi donasi, jumlah dana yang didonasikan lalu statusnya apakah sudah diverifikasi atau belum.

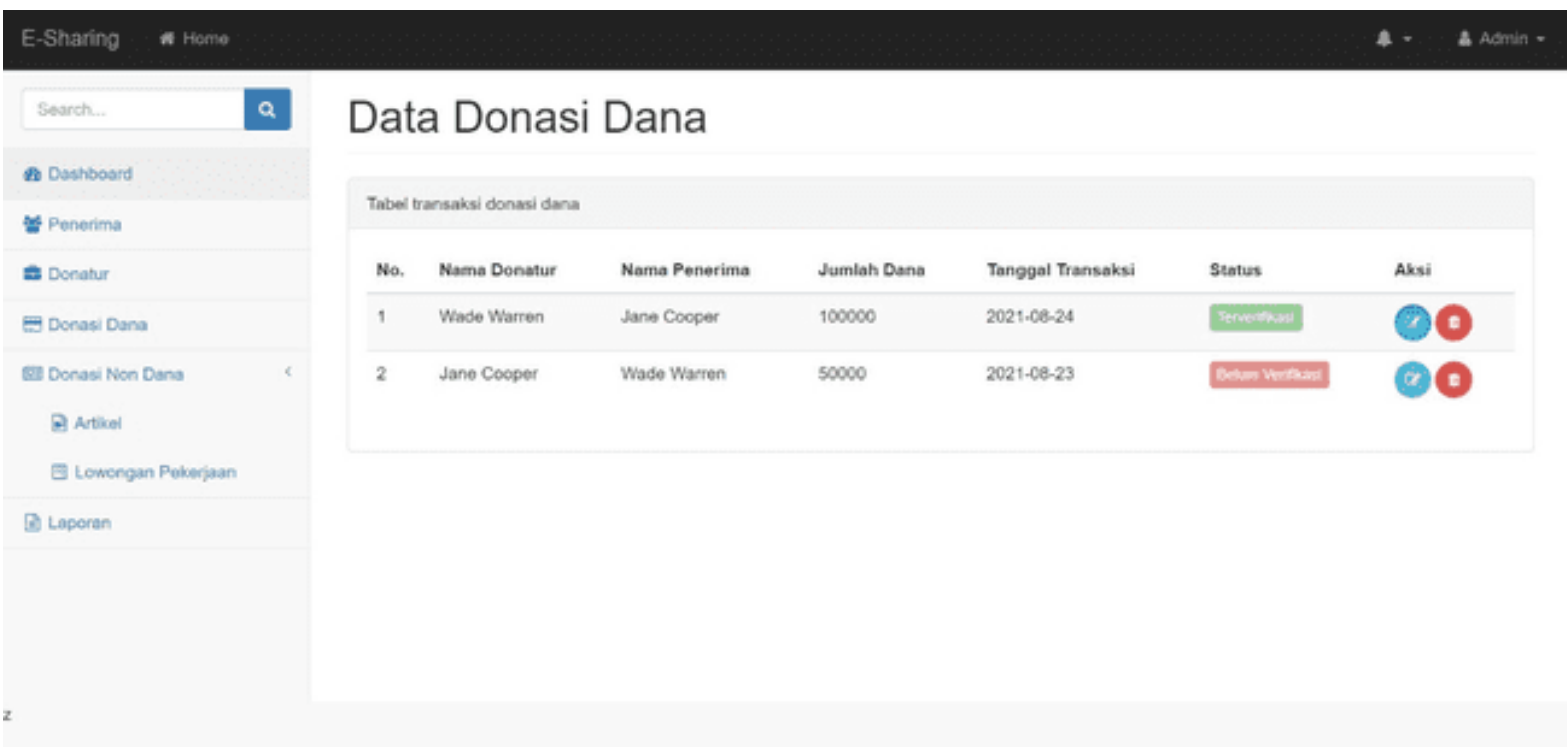

Gambar 12 Tampilan menu pemberi donasi

e. Tampilan penerima donasi

Pada gambar 13 disajikan mengenai informasi nama penerima donasi, yang berisi biodata dilengkapi dengan dokumen pendukung yaitu KTP, KK, dan Surat Keterangan di PHK.

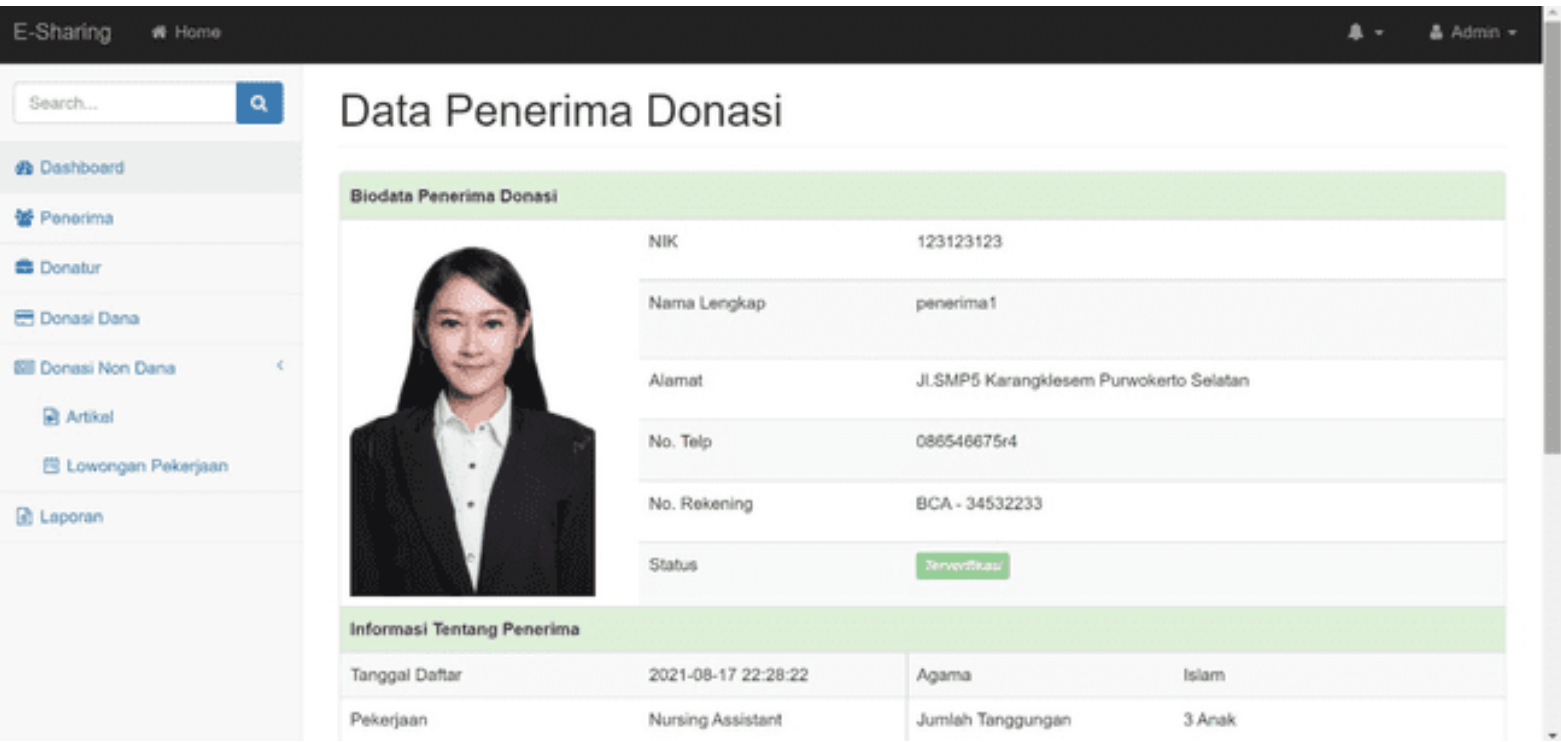

Gambar13. Tampilan menu penerima donasi 
f. Tampilan donasi non dana

Pada menu ini menampilkan informasi mengenai donasi non dana, dapat berupa sharing ide bisnis, artikel, video tutorial, lowongan pekerjaan, dll. Seperti pada gambar 14.

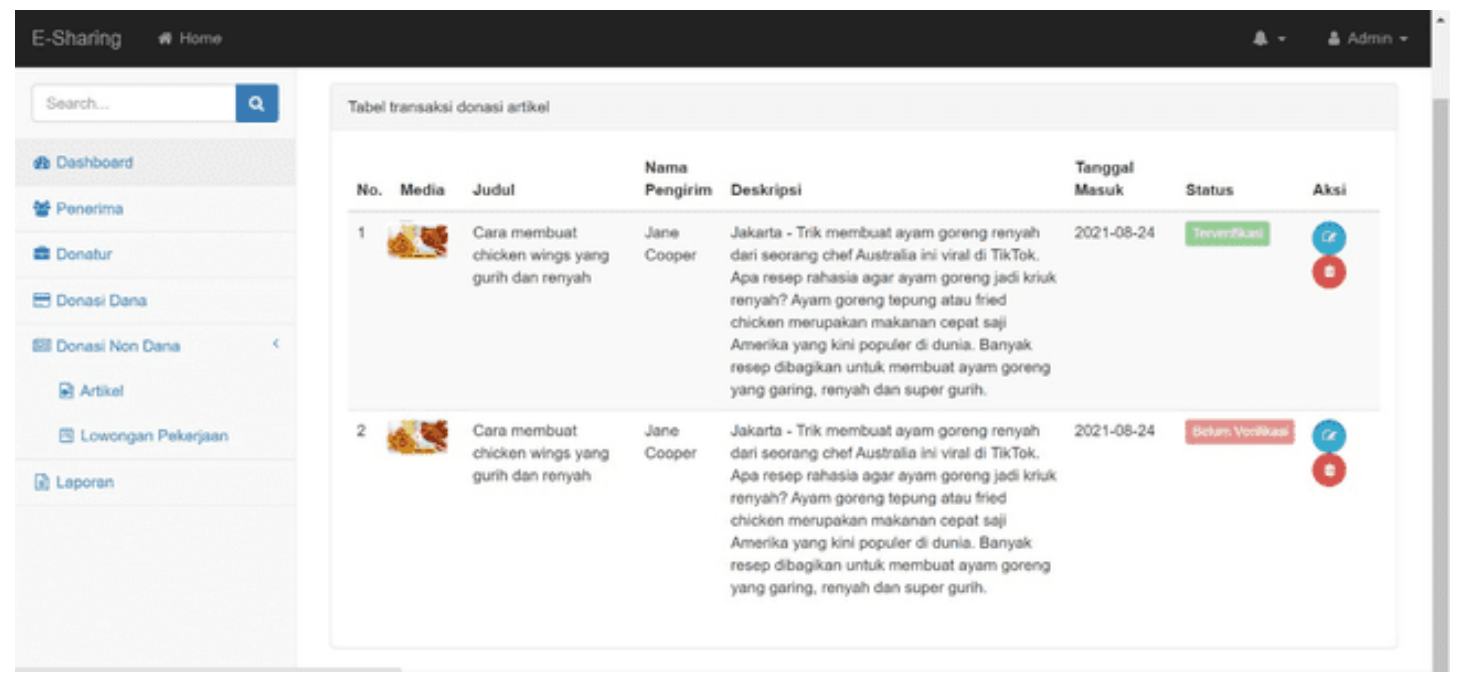

Gambar14. Tampilan menu donasi non dana.

\section{Tahap Pengujian Sistem.}

Terdapat 2 metode pengujian, yaitu whitebox testing dan blackbox testing.

White Box

Merupakan pengujian yang berpusat pada detail prosedur dan logika kode program sistem.

a. Login Admin

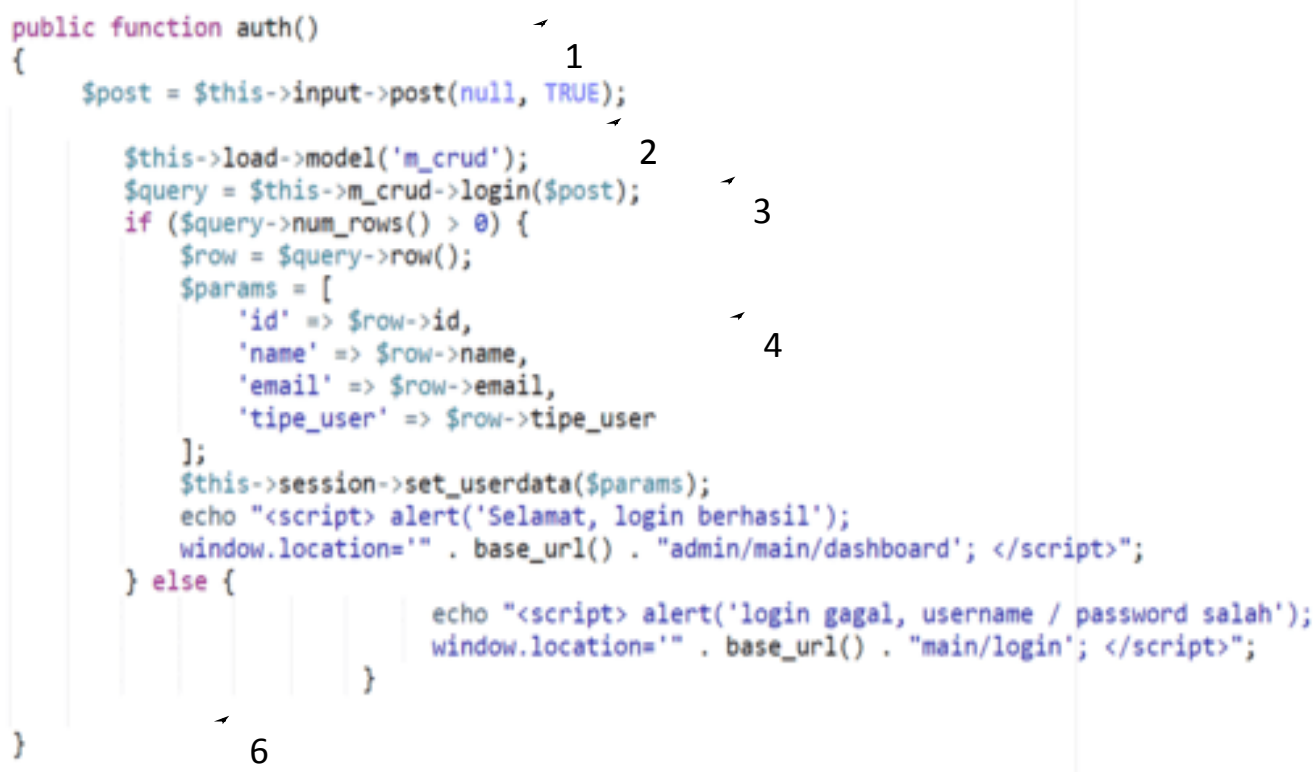

Gambar 15. Graph login admin

Pada pengujian proses login admin melalui website dimulai pertama kali saat fungsi "auth" (node 1) sistem akan menerima input berupa username dan password dari halaman login dan disimpan pada variable "post". Setelah variable "post" (node 2) memiliki value atribut username dan password, sistem kemudian mengirim request select melalui model "mcrud" berdasarkan atribut username dan password yang ada didatabase. Setelah mengirim request ke database 
selanjutnya respon dari database akan menjadi kondisi percabangan (node 3) dimana jika respon dari database menghasilkan baris data user yang memiliki kecocokan data maka selanjutnya yang akan dieksekusi adalah statement pada "if" (node 4) namun jika data respon tidak menghasilkan baris data user maka selnjutnya proses akan dialihkan pada statement else (node 5). Selanjutnya setelah proses (node 4) atau (node 5) selesai dieksekusi, program akan menjalankan proses akhir (node 6) dan melakukan return atau memberikan respon terhadap user berupa pesan dan tampilan hasil dari request yang dilakukan.

b. Login Users

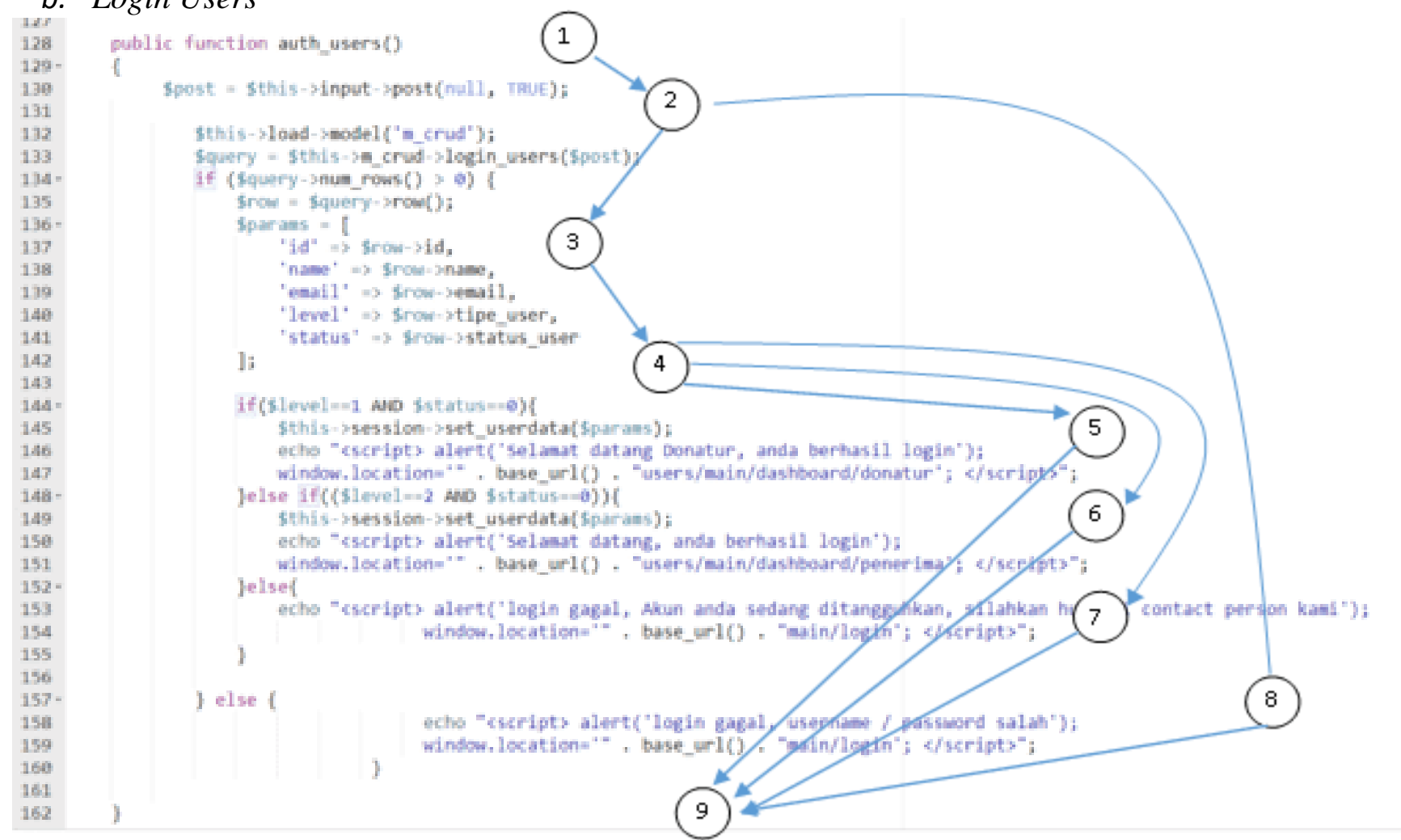

Gambar 16. Graph login user

Pengujian whitebox pada gambar 16 merupakan pengujian proses autentikasi pada web service yang diakses melalui menu login diperangkat mobile yang dimulai pada saat fungsi "auth_user", (node 1) dieksekusi, berikutnya proses request data ke database melalui model (node 2) akan dilakukan dan apabila respon dari database menghasilkan baris data user maka statement "if" (node 3) akan dieksekusi program dengan perintah menyimpan data hasil respon dari database ke variable array, sedangkan jika request tidak memberikan baris data maka statement "else" (node 8) akan dieksekusi dan menampilkan pesan gagal login sebelum akhirnya selesai pada akhir fungsi (node 9). Proses lanjutan dari statement "if" (node 3) berikutnya hak akses user akan dibedakan menjadi 3 (node 4), dimana level akses akan mempengaruhi menu berikutnya yang akan diakses. Apabila level user bernilai sama dengan ' 1 ' dan status user bernilai sama dengan 1 maka menu berikutnya yang akan diakses adalah menu yang diperuntukan bagi donatur (node 5), sedangkan apabila level user bernilai sama dengan 2 dan status aktif user bernilai sama dengan 1 maka statement "else if" (node 6) yang merupakan akses menu yang diperuntukan bagi anggota penerima bantuan. Namun jika level dan status user tidak diketahui maka akses akan login akan ditolak dan menampilkan pesan gagal login (node 7). Proses akan berakhir hingga fungsi “auth_user" ditutup. 


\section{Black Box}

Pengujian blackbox dilakukan pada menu login admin melalui website. Skenario uji blackbox dibagi menjadi lima skenario kasus yang berbeda untuk mengetahui respon sistem pada menu login di berbagai kondisi tersebut.

Tabel 2. Pengujian Blackbox

\begin{tabular}{|c|c|c|c|c|c|}
\hline No & Skenario Pengujian & Text Case & Hasil yang diharapkan & $\begin{array}{l}\text { Hasil } \\
\text { pengujian }\end{array}$ & $\begin{array}{l}\text { Kesimpula } \\
\mathrm{n}\end{array}$ \\
\hline 1. & $\begin{array}{l}\text { Username } \\
\text { Password tidak diisi } \\
\text { lalu tombol "Login" } \\
\text { diklik }\end{array}$ & $\begin{array}{l}\text { Username:(kosong) } \\
\text { Password:(kosong) }\end{array}$ & $\begin{array}{l}\text { Sistem akan menolak } \\
\text { dan menampilkan pesan } \\
\text { "Username dan } \\
\text { Password tidak boleh } \\
\text { kosong" }\end{array}$ & $\begin{array}{l}\text { Sesuai } \\
\text { harapan }\end{array}$ & Valid \\
\hline 2. & $\begin{array}{l}\text { Mengetikkan } \\
\text { Username dan } \\
\text { Password kosong atau } \\
\text { tidak diisi lalu klik } \\
\text { tombol "Login" }\end{array}$ & $\begin{array}{l}\text { Username:admin } \\
\text { Password:(kosong) }\end{array}$ & $\begin{array}{l}\text { Sistem akan menolak } \\
\text { dan menampilkan pesan } \\
\text { "Password tidak boleh } \\
\text { kosong" }\end{array}$ & $\begin{array}{l}\text { Sesuai } \\
\text { harapan }\end{array}$ & Valid \\
\hline 3. & $\begin{array}{l}\text { Mengetikkan } \\
\text { Password dan } \\
\text { Username kosong } \\
\text { tidak diisi lalu klik } \\
\text { tombol "Login" }\end{array}$ & $\begin{array}{l}\text { Username:(kosong) } \\
\text { Password:admin1234 }\end{array}$ & $\begin{array}{l}\text { Sistem akan menolak } \\
\text { dan menampilkan pesan } \\
\text { "Username tidak boleh } \\
\text { kosong" }\end{array}$ & $\begin{array}{l}\text { Sesuai } \\
\text { harapan }\end{array}$ & Valid \\
\hline 4. & $\begin{array}{l}\text { Mengetikkan } \\
\text { Username dan/atau } \\
\text { Password tidak sesuai, } \\
\text { lalu klik tombol } \\
\text { "Login" }\end{array}$ & $\begin{array}{l}\text { Username:adm } \\
\text { Password:adm }\end{array}$ & $\begin{array}{l}\text { Sistem akan menolak } \\
\text { dan menampilkan pesan } \\
\text { "Username atau } \\
\text { Password yang anda } \\
\text { masukan salah" }\end{array}$ & $\begin{array}{l}\text { Sesuai } \\
\text { harapan }\end{array}$ & Valid \\
\hline 5. & $\begin{array}{l}\text { Mengetikkan } \\
\text { Username dan } \\
\text { Password yang sesuai, } \\
\text { lalu klik tombol } \\
\text { "Login" }\end{array}$ & $\begin{array}{l}\text { Username:admin } \\
\text { Password:admin1234 }\end{array}$ & $\begin{array}{l}\text { Sistem akan menerima } \\
\text { akses lalu mengarahkan } \\
\text { ke halaman dashboard } \\
\text { Admin dan } \\
\text { menampilkan pesan } \\
\text { "Login berhasil, Selamat } \\
\text { datang Admin" }\end{array}$ & $\begin{array}{l}\text { Sesuai } \\
\text { harapan }\end{array}$ & Valid \\
\hline
\end{tabular}

Pada tabel 2 pengujian blackbox dapat dijelaskan sebagai berikut :

\section{Skenario 1}

Pada skenario pertama dilakukan dengan menekan tombol login dengan kondisi area untuk input username dan password dibiarkan kosong atau tidak terisi. Hasil yang diharapkan dari proses validasi adalah membatalkan proses request ke database dan menampilkan pesan bahwa username dan password tidak boleh kosong atau tidak terisi.

\section{Skenario 2}

Percobaan skenario kedua dilakukan dengan menginputkan username namun password dibiarkan kosong atau tidak terisi dan tombol login ditekan. Respon yang diberikan adalah sistem melakukan validasi atas atribut username dan password dan menampilkan pesan "Login Gagal" karena salah satu atribut kosong atau tidak terisi.

\section{Skenario 3}

Percobaan skenario ketiga dilakukan dengan menginputkan password namun username dibiarkan kosong atau tidak terisi dan tombol login ditekan. Respon yang diberikan adalah 
sistem melakukan validasi atas atribut username dan password dan menampilkan pesan "Login Gagal" karena salah satu atribut yaitu username bernilai kosong atau tidak terisi.

\section{Skenario 4}

Pada percobaan skenario ketiga username dan password diisi dengan nilai yang tidak terdaftar didatabase sistem. Setelah username dan password diisi dan tombol login kemudian ditekan, maka setelah validasi atribut username dan password dinyatakan terpenuhi karena masingmasing memiliki nilai. Selanjutnya system melakukan request untuk memanggil data user pada database berdasarkan nilai username dan atribut yang diisi oleh user namun data tersebut tidak ditemukan, maka system kemudian menampilkan pesan "Login gagal, username atau password salah".

\section{Skenario 5}

Skenario kelima dimana username dan password diisi dengan nilai yang sesuai salah satu data yang ada di database dan tombol login ditekan. Sistem melanjutkan prosesnya setelah validasi atribut username dan password terpenuhi ke proses request data ke database berdasarkan nilai yang sama antara nilai yang diisi user dengan yang ada di database. Selanjutnya system memberikan respon pesan "Login berhasil" dan halaman diarahkan ke halaman utama (dashboard).

\section{Pengujian Usability}

Tahap pertama yang dilakukan adalah menyiapkan responden. Responden ada 5 (lima) dengan karakteristik responden yang terdiri dari jenis kelamin, umur, dan jenis pekerjaan. Untuk karakteristik jenis kelamin responden terdiri dari 60\% laki-laki dan 40\% wanita. Sedangkan dari jenis pekerjaan terdiri dari $60 \%$ sebagai dosen/guru/pengajar, 20\% sebagai PNS, dan $20 \%$ sebagai mahasiswa/pelajar. Tahap kedua adalah menyebarkan kuesioner dengan Penyebaran kuesioner dilakukan secara daring melalui Google Form. Tahap ketiga adalah melakukan analisis hasil penyebaran kuisioner dengan SUS Score. Berikut hasil kuesioner yang sudah dihitung dengan rumus diatas, ditampilkan dalam Tabel. 3

Tabel 3. Hasil Penghitungan Skor SUS

\begin{tabular}{|c|c|c|c|c|c|c|c|c|c|c|c|}
\hline Responden & $\mathrm{R} 1$ & $\mathrm{R} 2$ & R3 & $\mathrm{R} 4$ & $\mathrm{R} 5$ & R6 & R7 & $\mathrm{R} 8$ & R9 & $\mathrm{R} 10$ & $\begin{array}{l}\text { Skor } \\
\text { SUS }\end{array}$ \\
\hline 1 & 5 & 1 & 5 & 3 & 5 & 2 & 5 & 1 & 5 & 4 & 85 \\
\hline 2 & 4 & 2 & 5 & 2 & 4 & 2 & 4 & 2 & 4 & 1 & 80 \\
\hline 3 & 5 & 1 & 5 & 1 & 5 & 1 & 5 & 1 & 5 & 3 & 95 \\
\hline 4 & 4 & 2 & 5 & 2 & 5 & 2 & 5 & 1 & 5 & 4 & 82.5 \\
\hline 5 & 4 & 1 & 5 & 1 & 5 & 1 & 5 & 2 & 4 & 2 & 90 \\
\hline \multicolumn{11}{|c|}{ Rata-rata Skor SUS } & 86.5 \\
\hline
\end{tabular}

Rata-rata skor SUS yang didapat menunjukkan tingkat penerimaan pengguna (Brooke, 2020). Dari Tabel 3, Berdasarkan hasil analisis yang dilakukan, rata-rata SUS Score adalah 86.5 itu berarti masuk dalam kategori Acceptable, dan dianggap excellent, serta masuk ke peringkat B. Skor SUS sebesar 82 atau lebih menunjukkan pengguna berpotensi menjadi promoter. Pada penelitian ini dapat disimpulkan bahwa Aplikasi e-sharing ini efektif, efisien dan memuaskan pengguna. 


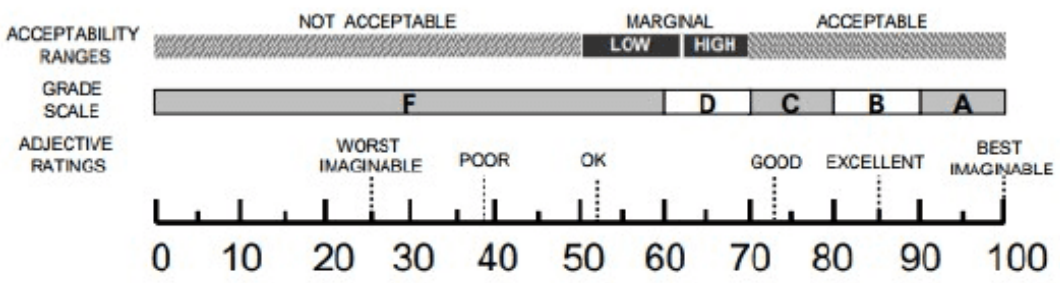

Gambar 17. Intrepretasi Skor SUS (Bangor dkk,2008)

\section{KESIMPULAN}

Sistem e-sharing adalah sebuah desain aplikasi fintech (Financial Technology) untuk memfasilitasi masyarakat yang berpenghasilan rutin dan jauh dari resiko kehilangan pekerjaan dengan perempuan korban PHK terdampak covid-19, dalam bentuk donasi maupun etalase/ide bisnis. Aplikasi $e$-Sharing ini layak digunakan karena efektif, efisien dan memuaskan serta dapat diterima bagi pengguna, hal ini dibuktikan dari pengujian yang telah dilakukan, antara lain uji whitebox dan blackbox dan hasil uji Usability dengan pengujian SUS (System Usability Scale) dengan nilai 86,5.

\section{Ucapan Terima Kasih (Acknowledgement)}

Dalam kesempatan yang berbahagia ini, penulis bersyukur dan menyampaikan terimakasih kepada DRPM DIKTI yan gtelah membiayai penelitian ini melalui Hibah Penelitian Dosen Pemula Tahun 2020.

\section{REFERENSI}

Bangor, A. et al. (2008) "An Empirical Evaluation of the System Usability Scale Usability Scale," 7318. doi: 10.1080/10447310802205776.

Brooke, J. (2020). SUS : A Retrospective. January 2013.

Burhanuddin, C. I., \& Abdi, M. N. (2019). Minat Masyarakat dalam Penggunaan Fintech. Riset \& Jurnal Akuntansi, 3(1), 1-27.

Dewi, M. M., Magdalena, F., Ariska, N. P. D., Setiyawati, N., \& Rumboirusi, W. C. B. (2020). Dampak Pandemi Covid-19 terhadap Tenaga Kerja Formal di Indonesia The Impact of Covid-19 Pandemic on Formal Labour in Indonesia. Populasi, 28(2), 32-53.

H.N, I. A., Nugroho, P. I., \& Ferdiana, R. (2015). Pengujian Usability Website Menggunakan System Usability Scale. JURNAL IPTEKKOM : Jurnal Ilmu Pengetahuan \& Teknologi Informasi, 17(1), 31. https://doi.org/10.33164/iptekkom.17.1.2015.31-38

Jusuf, C. (2007). Filantropi Modern Untuk. Filantropi Modern Untuk Pembangunan Sosial, 74-84.

Marthasari, G. I., \& Hayatin, N. (2017). Analisis Usability Terhadap Sistem Lective Gegulang Berbasis USE Qestionnaire. Jurnal Seminar Nasional Teknologi Dan Rekayasa (SENTRA), 1-8. http://research-report.umm.ac.id/index.php/sentra/article/view/1458

Nizar, M. A. (2017). Financial Technology ( Fintech ): It's Concept and Implementation in Indonesia. Munich Personal RePEc Archive, V(98486), 15.

Rusidi. (2011). Evaluasi Website EGoverment Instansi Pemerintah Daerah Kabupaten Ogan Komering Ulu Dan Ogan Komering Ulu Timur. http://Blog.Binadarma.ac.id/Akbar/ 2010/12 
Sari, E. K., \& Fikri Zufar, B. N. (2021). Perempuan Pencari Nafkah Selama Pandemi Covid-19. Al-Mada: Jurnal Agama, Sosial, Dan Budaya, 4(1), 13-29. https://doi.org/10.31538/almada.v4i1.1106

Steve, K. (1985). Emergency radiology in childhood. In Don't Make Me Think, Revisited A Common Sense Approach to Web Usability (Vol. 3, Issue 3). New Riders. https://doi.org/10.1097/01241398198601000-00078 